\title{
Teaching English Vocabulary to Young Learners via Augmented Reality Learning Media
}

\author{
Dias Agata \\ diasagata@pens.ac.id \\ Master in TEFL \\ Politeknik Elektronika Negeri Surabaya \\ Heny Yuniarti \\ heny@pens.ac.id \\ Master in Electronics Engineering \\ Politeknik Elektronika Negeri Surabaya \\ $\&$ \\ Ahmelia Ayu Pratiwi Adison \\ ameliadison@ce.student.pens.ac.id \\ Bachelor of Applied Science in Computer Engineering \\ Politeknik Elektronika Negeri Surabaya
}

\section{Article History}

Submited: 21-10-2020

Reviewed: 30-04-2021

Revised: 20-11-2021

Accepted: 26-11-2021

Keywords: Young Learners; Vocabulary; Augmented Reality.

DOI

https://doi.org/10.33508/bw.v9i2.2772

\begin{abstract}
This research aims to investigate the effect of teaching English vocabulary to young learners via Augmented Reality learning media. The subject of this research was 12 students of grade 1 elementary school. Due to strict health protocols during COVID-19 outbreak, the testing phase was done in students' respective homes accompanied by their parents using cell phones. Vocabulary illustrated in 30 three-dimensional objects and their written form were generated through cell phone's scanning. A quiz consisted of 54 multiple choice questions was provided after the interactive learning experience. Both the vocabulary and quiz were refer to Thematic English Exploration for Grade 1 book. The results showed that learning vocabulary using AR application was able to increase the mean evaluation score by $0.77 \%$. This application is effective in helping students improve their English language skills as approved by $76 \%$ of parents. The AR application was also approved by $59 \%$ of parents that it was easy to use. The AR application is proven to be convenience for students to learn English vocabulary interactively and feasible to be used as learning media.
\end{abstract}

\section{Introduction}

Since Corona Virus Disease 2019 local government started to establish strict (COVID-19) was declared a pandemic by the World Health Organization (WHO) as of March 11, 2020, there are many habits that health protocols, limit the number of activities that involve large numbers of people, apply social distancing and physical have to be changed worldwide. WHO and 
learn from home. The Indonesian government through the Ministry of Education and Culture has established the Decree of The Minister of Education And Culture of The Republic of Indonesia Number 719/P/ 2020 about Guidelines for Implementing The Curriculum in Education

LFH for young learners. Bruner (1996) reported the hierarchy of children's learning modes; the first is Enactive which means depending on physical activity, the second is Iconic which represents residual mental images resulting from the contacts with material entities, and the third is Symbolic which is obtained through symbolic medium, one of them is language learning. In order to facilitate young learners learning from home, an interactive learning media has to be provided.

The term "young learner" covers a large age span from 3 years old to 15 (Nunan, 2010). This wide age range made the researchers set limits to only focus on young learners at the early elementary school age, six to eight years old. Learning English for young learners in elementary schools in Indonesia is basically just an introduction to English. The material taught is in accordance with the 2013 curriculum. The development of the English curriculum can be prepared by the students and the school's environment.

Pinter (2017) wrote about the characteristics of young learners in learning English as a Second Language. Students considered as young learners if they are in the first year of preschool or primary school, they have not mastered the ability to write and read, and better learning using fantasy, imagination and movement. One way to create interactive learning experiences for young learners is by using the Augmented Reality (AR) technology
Units in Special Conditions which set the rules of online learning system from home during COVID-19 outbreak in Indonesia published on March 2020.

Implementing learn from home (LFH) requires extra cooperation and attention from the school and parents. Especially system. AR is a technology that combines two-dimensional or three-dimensional virtual objects with the real world in real time (Indriani, et. al., 2016). In contrast to VR (Virtual Reality) which completely replaces a reality, AR simply adds an object to a real state. Various fields have implemented AR to facilitate the work, including the fields of medical, military training, entertainment, machine design, as well as education.

AR in education has the advantage of stimulating students' interaction and making it easier for students to learn foreign languages (Vate-U-Lan, 2012). This is because AR is applied to an application that provides many options for students compared to those who use only passive way to learn. AR is a technology that can be applied to computers and mobile devices, so that it can be accessed anywhere and at anytime. AR has been implemented to improve language skills, such as learning English in the form of three-dimensional pop-up books (Vate-ULan, 2012), vocabulary learning, and as a storytelling medium through the Pokemon GO application (Godwin -Jones, 2016).

Dolkar, et. al. (2016) reported that a learning media has to meet some requirements: (1) the ability to make students focus on the material being studied, (2) interesting content, (3) features that can facilitate the learning process, and (4) other additional options to facilitate underachieving students. The learning 
media created in this research is named "Learning English with AR for Grade 1". The main reference in making the learning media is Thematic English Exploration Book 1 which is containing English material for grade 1 elementary school written by Djoko Semedi and refers to the
2013 Curriculum (K-13). "Learning English with AR for Grade 1" is an Android application made by utilizing AR technology. This study focuses on analyzing the results of the application of "Learning English with AR for Grade 1" for young learners.

\section{Research Question}

The purpose of this research is to investigate the effect of teaching English vocabulary to young learners by using Augmented Reality learning media. The interactive English learning media with Augmented Reality (Learning English with AR for Grade 1) has been created on the Android platform (Agata, et.al. 2020), and

\section{Literature Review}

\section{Young Learners}

Young learners are children who learn with age span from 3 to 15 years old (Nunan, 2010). They have a distinctive characteristic in learning. When they learn a language, they can understand the meaning of the message but cannot analyze the language. They are very limited in terms of reading and writing skills. They are also still in the stage of caring more about themselves than their environment and in the learning process, they will prefer movement, fantasy and imagination (Pinter, 2017). There are five major challenges teacher of young learners encounter: cognitive development, motivation, attention span, multilevel groups and assessment (Nunan, 2010). To overcome the challenges, teacher's role is needed to clarify learning objectives, selectively choose content that facilitate young learners to learn, encourage collaborative learning, vary learning the current research is focusing on the analysis of the effects of teaching English vocabulary to young learners using Augmented Reality learning media. In accordance with the purpose of the study, the following research question was formulated: How is the effect of teaching English vocabulary to young learners using Augmented Reality learning media?

activities and comprehend the special needs of young learners.

\section{Young Learner's Vocabulary Size}

Vocabulary is one of the most essential components of competence in foreign language learning (Nikolov, 2009). The result of research conducted by Orozs in Hungary (2003) quoted by Nikolov (2009) shows that after four years of English language learning, young learners have an active knowledge of 600, and an additional passive knowledge of 250 vocabulary items. The development of young learners in learning second language involves three dynamic processes: cognitive development, ongoing development of the first language, and a relatively new process related to the second language acquisition.

\section{Augmented Reality}

Augmented Reality (AR) is a technology that combines the real and artificial worlds using a computer. Artificial objects that are combined into the real world 
can be two-dimensional or threedimensional objects (Indriani, et. al., 2016). The architecture of AR according to Indriani, et.al. (2016) includes: (1) Input in the form of images, the magnitude of the vibration sensor, the magnitude of the location sensor, and the magnitude of the vibration sensor. (2) A camera or other sensor that functions as a receiving device and makes it an information which will be processed by the processor. (3) A processor that functions to process information received by cameras and sensors to make it as output (4) Output that displays the results of information that has been processed from the processor section. Results can be seen on monitors, cellphone screens, and so on.

\section{Learning English with Augmented Reality for Grade 1}

This study will investigate the effect of interactive learning media named "Learning English with Augmented Reality for Grade 1 " which is the product of a result conducted by Agata, et.al (2020) on improving the English ability of grade 1 elementary school students. Teaching materials and exercises or evaluations adopted for interactive learning media come from a book used by grade 1 elementary school students entitled Thematic English Exploration 1 compiled by Djoko Semedi which refers to K-13.

This interactive learning media can be accessed using an android phone. Before this learning media is used, students need to prepare an android phone with the application "Learning English with Augmented Reality for Grade 1" which has been uploaded to the cellphone. Then students can start scanning the pictures in the module book whose contents match the material from the reference book. As the result as shown in Fig.1., students will get a scanned object image in the form of a three- dimensional object and the name of the object written. The results of this study have been able to generate 23 three-dimensional AR objects and 7 two-dimensional AR objects.
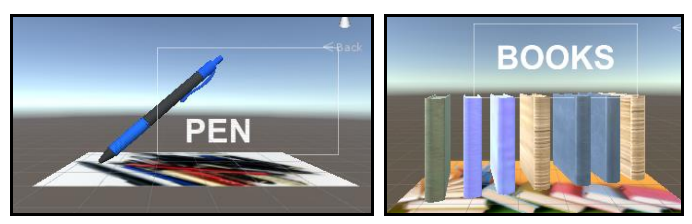

Fig.1. Three-dimensional objects as the results of scanning

After learning vocabulary using interactive learning media "Learning English with Augmented Reality for Grade $1 "$ students can also test their comprehension independently by taking the evaluation provided in the application. Evaluation aims to measure students' understanding of learning vocabulary that has been done before. The evaluation was adjusted to the contents of the reference book, which contains 54 questions. The evaluation display was designed interactively as shown in Fig. 2 and Fig.3. There will be notification for correct answer (happy smiley) and notification for incorrect answer (sad smiley).

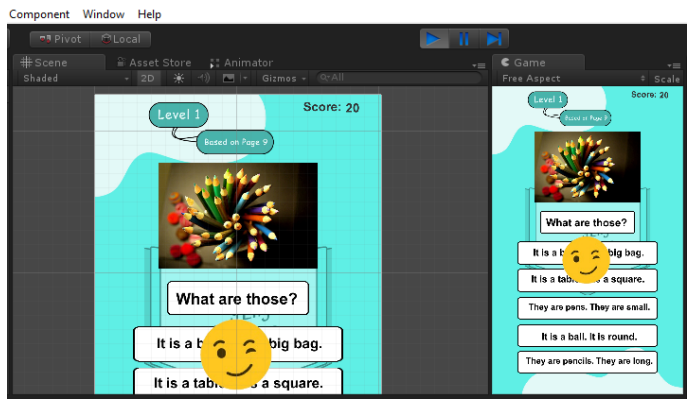

Fig.2. Notification for correct answer

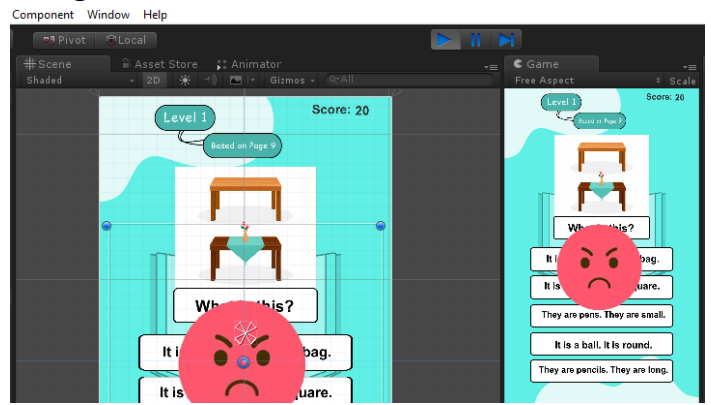

Fig.3. Notification for incorrect answer 
A measured investigation is needed to determine the impact of using this application (Agata, et.al., 2020) on improving young learners' English skills.

\section{Likert Scale}

Likert scale is a scale that aims to measure opinions, attitudes, and the level of satisfaction of a person or group of people and is commonly used for scales in questionnaires. The levels on the Likert scale are a gradation from negative to positive answers (Budiaji, 2013). This study uses a Likert scale which has a gradation of 5 levels, which at each level of gradation there are values 1 to 5 . Value 1 for "strongly disagree" response, value 2 for "disagree" response, value 3 for "neutral" response, value 4 for "agree" response, and value 5 for "strongly agree" response.

\section{Method}

The testing phase began by distributing a digital version of manual book containing the steps before installing the Learning English With AR application and procedures after the application was installed on the cellphone. This is necessary

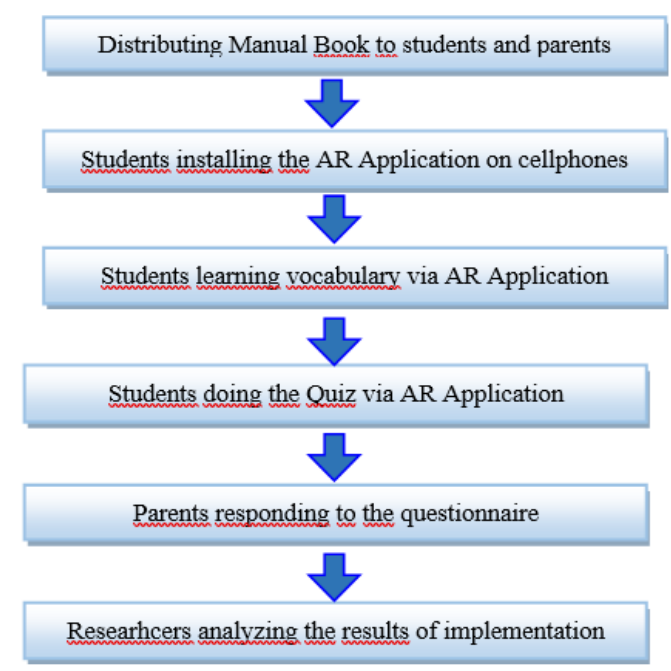

Fig.4. Block diagram of test implementation stage

As illustrated in Fig. 4, the implementation phase was first carried out on 12 students with qualification of first grade in elementary school. The implementation was done in their respective homes accompanied by their parents using cell phones. The AR application is uploaded to Google Drive and then the link from the AR because during the trial process, researchers could not meet with the respondents (students) and their parents due to health protocols related to the COVID-19 outbreak. The test implementation stage is depicted in Fig. 4 below.

application is shared with the parents along with the manual and module in digital form. In the second stage, students were learning English vocabulary with the AR application which contains 30 three-dimensional objects and their written form that can be scanned using cell phones. Then, after studying the English vocabulary via the AR application, students were doing a quiz for evaluation. The quiz consists of 54 multiple choice questions adopted from Thematic English Exploration for Grade 1 book. After a series of interactive learning processes using the AR application and the quiz had been completed by the students, parents filled out a questionnaire with a Likert scale prepared to measure the following points: (1) The relevance of manuals and modules with AR applications, (2) The effectiveness of AR application in improving students' English proficiency (especially vocabulary), (3) The convenience of using AR application by students. 


\section{Results and Analysis}

Before implementing the application in students' learning activity, previously students were asked to learn vocabulary in course book conventionally and worked on questions on quizzes in course book without using the AR application as a learning media. The quiz scores obtained by the students before using AR were then compared with the students' scores after learning vocabulary using AR application and doing quizzes with the AR application. Table 1 below shows the results of student scores before and after using the AR application.

The results of the comparisons in Table 1 depicted that there are 7 students or $58 \%$ of the total respondents whose scores are remaining, both before and after using the AR application. 1 student or $9 \%$ of the total respondents got lower score after using the AR application and 4 students or $33 \%$ of the total respondents got higher scores after learning and filling out quizzes using the AR application. This is consistent with what Table 1.

Score comparison before and after using AR application

\begin{tabular}{clcc}
\hline No. & \multicolumn{1}{c}{ Student's Name } & $\begin{array}{c}\text { Score Before Using AR } \\
\text { Application }\end{array}$ & $\begin{array}{c}\text { Score After Using AR } \\
\text { Application }\end{array}$ \\
\hline $\mathbf{1}$ & Naurah Kirana Qaris & 53 & 53 \\
\hline $\mathbf{2}$ & Zahra Amira Ramadhani & 46 & 46 \\
\hline $\mathbf{3}$ & Talitha Nurul Ainy Habibi & 53 & 53 \\
\hline $\mathbf{4}$ & Adrian Maulana Rianto & 50 & 50 \\
\hline $\mathbf{5}$ & Nayla Hufairoh Shidiqiyah & 53 & 54 \\
\hline $\mathbf{6}$ & Jihan Tri Nafisah & 53 & 52 \\
\hline $\mathbf{7}$ & Thalita Maulidyah Putri & 53 & 53 \\
\hline $\mathbf{8}$ & Keyla Pesiwarissa & 52 & 53 \\
\hline $\mathbf{9}$ & Jelita Naura Azzahra & 54 & 54 \\
\hline $\mathbf{1 0}$ & Devon Jazz Alvaro Putra & 49 & 54 \\
\hline $\mathbf{1 1}$ & Ayat Fitra Sakti Wahyudi & 53 & 54 \\
\hline $\mathbf{1 2}$ & Davino Kenzie Valora & 54 & $\mathbf{5 2 . 3}$ \\
\hline & Average & $\mathbf{5 1 . 9}$ & \\
\hline
\end{tabular}

Pinter (2017) reports that young learners enjoy a learning atmosphere that involves fantasy, which in the AR application, this fantasy can be represented by threedimensional objects generated by the AR application.

There is a mean increase of $0.77 \%$ from the score before and after using AR. The increase is insignificant, but it is enough to prove that $A R$ in education has the advantage of stimulating students' interaction and making it easier for students to learn foreign languages (Vate-U-Lan, 2012).

There were three statements that 12 parents from 12 students need to respond to on a Likert scale (strongly agree to strongly disagree) in the questionnaire. The statements are: (1) manuals and modules are relevant to AR applications, (2) AR applications are effective in helping improve students' English proficiency, (3) AR applications are easy for students to use. Table 2 summarizes the results of the parents' responses to the questionnaire. 
Table 2

Questionnaire responses from parents

\begin{tabular}{cccccc}
\hline \multirow{2}{*}{ Statement } & \multicolumn{5}{c}{ Number of responses } \\
\cline { 2 - 6 } & $\begin{array}{c}\text { Strongly } \\
\text { Disagree }\end{array}$ & Disagree & Neutral & Agree & $\begin{array}{c}\text { Strongly } \\
\text { Agree }\end{array}$ \\
\hline (1) & 0 & 2 & 3 & 2 & 5 \\
\hline (2) & 0 & 1 & 2 & 5 & 4 \\
\hline (3) & 0 & 3 & 2 & 5 & 2 \\
\hline
\end{tabular}

Table 2 illustrates that of all the statements in the questionnaire, no one responded to strongly disagree. 59\% of parents agree and strongly agree that manuals and modules are relevant to $\mathrm{AR}$ applications, meanwhile $25 \%$ of parents say they are neutral and $16 \%$ or as many as 2 parents disagree with this statement.

Seventy-six\% of parents agree and strongly agree that AR applications are effective in helping improve students' English proficiency, some parents admitted that the AR application was helpful to become a learning medium at home because it can facilitate their children who are not adept yet at writing and reading. This corresponds to Pinter (2017) statement that one of the characteristics of young learners is that they are not yet proficient in reading and writing so they require interactive learning media.

More than half of respondents or parents $(59 \%)$ agree and strongly agree that AR applications are easy for students to use. Parents can easily facilitate children to use AR applications on cellphones. Parents also gave suggestions to add a feature to spell the names of the objects displayed in the AR application to enrich students' understanding of vocabulary. The constructive input can be considered for the application development in further research.

The overall positive responses obtained from parents make it all clear that this AR application is a feasible application to be used in the interactive learning process as one solutions of learning media during LFH period.

\section{Conclusion}

The effect of teaching English vocabulary to young learners using Augmented Reality learning media is the increase in the average score of $0.77 \%$ from the score before and after using the AR application. It was enough to prove that $A R$ in education has the advantage of stimulating students' interaction and making it easier for students to learn foreign languages.

Based on the responses of parents who assist students in learning using the AR application, it was revealed that $59 \%$ of parents agree that manuals and modules are relevant to AR applications. $76 \%$ parents also agree that AR applications are effective in helping improve students' English proficiency, and $59 \%$ of parents agree that the AR application was easy to use. These positive responses support that the $A R$ application was evidently feasible to be used as one of learning media for young learners. 


\section{References}

Agata, D. Yuniarti, H. Adison, A. (2020). Android Based English Learning Media and Quiz Using Augmented Reality. Proceedings of International Conference on Applied Science and Technology, Padang: Oct. 24-25, 2020.

Bruner, J. (1996). The Culture of Education. Cambridge, Massachusetts: Harvard University Press.

Budiaji, W. (2013). Skala Pengukuran dan Jumlah Respon Skala Likert. Jurnal Ilmu Pertanian dan Perikanan, vol. 2, no. 2, pp. 127-133, 2013.

Dolkar, K. Bidha, C. Tshering, S. Thinley, D. Dhungyel, P. (2017). Interactive Dzongkha Learning Apps for Kids. Phuentsholing: Royal University of Bhutan Rinchending.

Godwin-Jones, R. (2016). Augmented Reality and Languange Learning: From Annotated Vocabulary To Place-Based Mobile Games. Language Learning \& Technology, vol. 20, no. 3, hh 9-19.

Indriani, R. Sugiarto, B. Purwanto, A. (2016). Pembuatan Augmented Reality Tentang
Pengenalan Hewan Untuk Anak Usia Dini Berbasis Android Menggunakan Metode Image Tracking Vuforia. Yogyakarta: Seminar Nasional Teknologi Informasi dan Multimedia.

Nikolov, M. (2009). Early Learning of Modern Foreign Languages: Processes and Outcomes. Bristol: Multilingual Matters.

Nunan, D. (2010). Teaching English to Young Learners. California: Anaheim University Press.

Pinter, A. (2017). Teaching Young Language Learners, Second Edition. Oxford: Oxford University Press.

Vate-U-Lan, P. (2012). An Augmented Reality 3D Pop-Up Book: the Development of a Multimedia for English Language Teaching. Bangkok: University of Thailand.

\section{Authors' Bio}

\section{Dias Agata}

Dias Agata, S.S., M.Pd. is a Lecturer at Computer Engineering Study Program at Politeknik Elektronika Negeri Surabaya (PENS), where she teaches English, Communication Skills and Entrepreneurships. She is experienced in pedagogy, public speaking and an entrepreneurship enthusiast. Dias recently serves as secretary of PENS International Cooperation Office and provides access for students, lecturers and researchers to broaden and strengthen their collaborations with overseas partners. Please email diasagata@pens.ac.id to contact Dias.

\section{Heny Yuniarti}

Heny Yuniarti, S.ST., M.T. is a Lecturer at Computer Engineering Study Program, Politeknik Elektronika Negeri Surabaya, where she teaches Sensor and actuator, Electronic Circuit and Electrical measurement. She is experienced in electro biomedic hardware. Heny has successfully supervised computer engineering students in PKM to go to PIMNAS. Please email heny@pens.ac.id to contact Heny. 
Ahmelia Ayu Pratiwi Adison

Ahmelia Ayu Pratiwi Adison is an alumni of Computer Engineering Study Program, Politeknik Elektronika Negeri Surabaya. Ahmelia is currently focusing on her project about creating Augmented Reality learning media to teach English. Please email ameliadison@ce.student.pens.ac.id to contact Ahmelia. 